\title{
Oppimisen muodonmuutoksia:
}

\section{KEHITYS KAMELEONTTIEN AIKAKAUTEEN}

PEKKA SALLILA (toim. 2003) Elämänlaajuinen oppiminen ja aikuiskasvatus. Aikuiskasvatuksen 44. vuosikirjasta. Kansanvalistusseura ja Aikuiskasvatuksen Tutkimusseura ry.

Vuonna 1969 aikuiskasvatuksen (tuolloin vapaan sivistystyön) vuosikirjan teemana oli alun perin Unescon lanseeraama elinikäinen kasvatus. Noihin aikoihin verrattuna ilmiö käsitteellistetään nykyään laajemmaksi. Oppimisen käsitteellä halutaan korostaa oppijaa aktiivisena toimijana entisen, ehkä hiukan holhoavankin kasvattajien ja instituutioiden näkökulman sijasta. Koulivaa kuria kaipaavien jukuripäiden asemesta kansalaiset nähdään nyt oman oppimisensa autonomisina rakentajina. Enää ei myöskään tyydytä siihen, että oppimisen ja itsensä kehittämisen nähtäisiin jatkuvan ihmisen koko eliniän; nyt kaikki elämänalueet pitäisi nähdä oppimisen areenoina. Vaikeatkin käänteet elämässään "haasteina" ottava ihminen oikein hakeutuu tilanteisiin, joissa saa tilaisuuden oppia uutta.

Aikuiskasvatuksen 44. vuosikirja koostuu kahdeksasta artikkelista, joissa tätä koko elämän kestävää ja kaikilla elämänalueilla tapahtuvaa prosessia ja sen edistämiseksi harjoitettua politiikkaa valotetaan eri näkökulmista. Kokeneempaa tutkijakaartia edustavat professorit Ari Antikainen, Risto Rinne ja Jukka Tuomisto, jotka Markku Leinosen ohella vas- taavatkin kirjan tärkeimmästä annista. Nuorempi polvi rajautuu tarkasteluissaan suppeampiin näkökulmiin (avoimen yliopiston opiskelijan muotokuva, työmarkkinoille siirtyvien nuorten uudenlaiset ongelmat, ikääntyvien pitkäaikaistyöttömien ohjaava koulutus). Puolet kirjoittajakunnasta on Turun yliopistoon hiljattain perustetusta Elinikäisen oppimisen ja koulutuksen tutkimuskeskuksesta CELEstä, joka on moninaisilla tutkimushankkeillaan ja ahkeralla julkaisutoiminnallaan nostanut itsensä nopeasti keskeiseen asemaan aikuiskoulutustutkimuksen kentällä.

\section{POHJANA KASVATUSUTOPIAT}

Kirjan aluksi Markku Leinonen jäljittää elinikäisen ja elämänlaajuisen oppimisen ideaa 1500ja 1600-luvuille Thomas Moren Utopia-teoksesta ja Johan Amos Comeniuksen kirjoituksista vetäen näistä yhtymäkohtia myös Antiikin ja juutalais-kristillisen tradition ajatteluun. Kasvatusutopioissa oppiminen on luonnostaan elämänlaajuista kuuluen niin arkeen kuin juhlaan - koulutukseen, työhön, vapaaaikaan. Utopiassa "kansalaiset voisivat mahdollisimman paljon olla vapaina ruumiillisesta työstä ja omistaa aikaansa vapaaseen hengenviljelyyn - - Tässä on heidän mielestään elämän onni." Utopiassa valtion välttämättömien tarpeiden täyttämisen jälkeen kansalaiset voivat omistautua kokonaan omien kiinnostustensa mukaisiin opintoihin. Omien mieltymysten mukainen itsensä kehittäminen kuului jokaiselle.

Niin Moren kuin Comeniuksen idealismi näkyy myöhemmin esimerkiksi Unescon 1960luvulla (uudelleen) lanseeraamissa koulutusta koskevissa ajatuksissa. 2000-luvulla eurooppalaiseen sivistystraditioon kuuluvien kasvatusutopioiden sisältämä humanistinen toiveikkuus ihmisten "henkistymisestä” on monin kohdin kääntynyt päälaelleen, kun oppimisen ja osaamisen sisällön ja tahdin määräävät markkinavälitteisen tuottamisen ja kuluttamisen liikevoimat.

Utopioissa ihminen muokkasi maailmaa omien tavoitteidensa mukaiseksi voidakseen toteuttaa paremmin itseään. Nykyyhteiskuntien aineellinen vauraus on jo ylittänyt utopioissa haaveillut edellytykset irrottautua pakonomaisesta ja kokonaan yksilön ulkopuolelta määräytyvästä työnteosta. Paradoksaalisesti nyt ihanteena kuitenkin on kameleontti, joka muokkaa itsensä ympäristön mukaiseksi vaikka välillä koville ottaa.

\section{TASA-ARVO JA \\ OIKEUDENMUKAISUUS}

Jukka Tuomisto täydentää Leinosen aloittamaa käsitehistoriallista ruodintaa erottaen elinikäisen oppimisen diskurssissa Kjell Rubensonin tapaan kaksi sukupolvea. Keskustelun ensimmäistä aaltoa puhalteli eteenpäin Unesco 1960-luvulla, jolloin elinikäinen oppiminen liitettiin kiinteästi yhteiskunnallisen oikeudenmukaisuuden ja tasa-arvon tavoitteluun. 
Toisen sukupolven veturina toimi talouselämä keulakuvanaan OECD 1980-luvulla, jolloin elinikäinen oppiminen kytkettiin kansantalouksien pyrkimyksiin lisätä työllisyyttä, taloudellista tuottavuutta ja tehokkuutta sekä kansainvälistä kilpailukykyä. Tuomisto tiivistää artikkelissaan kansainvälisten järjestöjen, kuten Unescon, OECD:n ja EU:n perusajatukset elinikäisestä oppimisesta muun muassa näiden tuottamien asiakirjatekstien pohjalta.

Nykyisin kansainvälisessä keskustelussa vaikuttaa implisiittisesti kaksi erilaista käsitystä elinikäisestä oppimisesta. $L i$ felong education -käsitteessä korostuu systemaattinen oppilaitoksissa tapahtuva oppiminen organisoituine opettamistilanteineen; lifelong learning taas painottaa enemmän informaalista ja itseohjautuvaa oppimista. Vaikka käsitteitä käytetään monta kertaa tarkoittamaan samaa asiaa, käytännön koulutuspoliittisiksi linjauksiksi ja toimenpiteiksi konkretisoituna ne poikkeavat selvästi toisistaan. Jälkimmäinen on nykytilanteeseen nähden sikäli radikaalimpi, että sen toteuttaminen edellyttää instituutioiden ja ajan mittaan erillisiksi muotoutuneiden toimintojen välisten rajaaitojen kaatoa ja ylitystä.

Kaikesta oppimisesta arvioilta kolme neljäsosaa tapahtuu informaalisti arkielämän kokemusten kautta. Kokemusperäinen oppiminen on tässä mielessä kouluoppista "luonnollisempaa", mutta koulutuksen ammattilaiset ja koulutuspolitiikan tekijät rajaavat oppimista koskevan näkökulmansa vain helpommin havainnoitavaan toimintaan koulumuotoon organisoiduissa instituutioissa.
Alun perin paljolti Ruotsissa käytetyssä käsitteessä 'elinikäinen ja elämänlaajuinen oppiminen' (livslångt ach livsvitt lärande) erottuu kaksi ulottuvuutta: ihmisen elämänkulussa jatkuva prosessimainen kokemusten kasaantuminen ja eri elämänsektoreiden yhdenvertaisuus oppimisareenoina. Ruotsalaisten käyttämän käsitteen alkuosa viittaa aikanaan Unescon näkemykseen, jossa oppimisen vertikaalisella integraatiolla viitattiin peräkkäisten oppimismahdollisuuksien yhdentämistä koko ihmisen eliniän kattavaksi jatkumoksi. Horisontaalinen integraatio taas tarkoitti eri elämänalueilla (koulutuksessa, työelämässä, järjestöissä, perhepiirissä, medioissa, kirjastoissa jne.) tapahtuvan toiminnan ja oppimisen yhdentämistä kokonaisuudeksi.

Paljolti samat asiat toistetaan eri aikoina eri käsitteillä. Tuomisto haluaa kuitenkin muistuttaa, että käsitteiden käyttäjillä on aina jotkin tarkoitusperät käyttää tiettyjä käsitteitä ja antaa tietty sisältö käyttämilleen käsitteille: olisi tarpeellista keskustella siitä, mihin kukin diskurssillaan pyrkii, kuka suostuttelee ketä ja millä keinoin.

Aina ei elinikäistä ja elämänlaajuista oppimistakaan voi pitää neutraalina kaikkien yhteiskunnan toimijoiden ja ryhmien etua ajavana periaatteena. Se, millaisina käytännön toimina periaate konkretisoituu, on poliittinen, vallankäytön oikeutukseen, liittyvä kysymys. Käytännön toiminnaksi muuntuneella elinikäisellä oppimisellakin on monia tarkoittamattomia ja eitoivottuja seurauksia riippuen siitä, minkä yhteiskuntaryhmän näkökulmasta käytäntöä tutkitaan. Myös tästä on koko elä- män "opinnollistamisessa" kysymys, kuten sosiologisesti suuntautuvat tutkijat jaksavat muistuttaa. Mutta, kuten Tuomistokin huomauttaa, maailman mitassa aikuiskoulutuspolitiikka kamppailee sellaisten peruskysymysten, kuten lukutaidottomuuden vähentämisen ja väestön peruskoulutuksen kanssa.

\section{KEIDEN "ILO"?}

Risto Rinne puolestaan tarkastelee elinikäisen oppimisen retorisia lupauksia viimeaikaisten suomalaisten politiikkadokumenttien pohjalta. Tavallaan Rinne siis jatkaa retoriikan ruotimista siitä, mihin Tuomisto päätyi. Esimerkiksi jatkuvan koulutuksen toimikunnan mietinnöstä (Kom. miet. 1982:63) luettavan "vanhan retoriikan" pääpaino oli jo monin tavoin yhteiskuntakehityksen edistämisessä, mutta myös yksilöiden suotuisan kehityksen tukemisessa. Vuonna 1997 julkaistun "Oppimisen ilo" -mietinnön Rinne taas liittää uusliberalistiseen markkinauskoon, ja siinä tuotantoelämän uudet tehostamistarpeet saavat ajanmukaisen ilmaisun koulutuspolitiikan kielellä. Mietinnössä iloinen oppija ryntää intoa puhkuen kohti kiristyvän kilpailun avaamia "haasteita". Vuonna 2002 julkaistun parlamentaarisen aikuiskoulutustyöryhmän mietinnön (Kom 2002:3) yhteiskuntakuvaa Rinne pitää realistisempana, vaikka senkin diskurssi paljolti ammentaa voimaansa utopistisesta retoriikasta.

Komitearetoriikassa koulutuksen tavoitteiden esitetään olevan "yhteiskunnan", "työelämän" ja "talouden" asettamista vaatimuksista johdettuja. Mietintöteksteissä esimerkiksi "yhteiskunnalla" kerrotaan olevan 
erilaisia tarpeita, joihin kansalaisten olisi vastattava. "Yhteiskunta" asettaa haasteita, ehtoja ja vaatimuksia. Yhteiskunta on kansalaisiin nähden jotain ulkopuolista, mutta varsinaista toimijaa ei yleensä identifioida. Retoriikassa ei kaivauduta pintaa syvemmälle todellisuuteen, jossa itse "yhteiskunta" koostuu ihmisistä ja ryhmistä, joilla on eri määrä valtaa ja voimavaroja toteuttaa tarkoitusperiään.

"Markkinoiden vaatimusten", "globalisaation" yms. aiheuttamien muutosten perimmäistä mielekkyyttä sinänsä ei kyseenalaisteta. Koulutuspolitiikka on joukko tekniikoita, joita soveltamalla kansalaiset mukautuvat toimimaan niin, että "talous" saa "vaatimansa", "globalisaatio" voi edetä esteettä ja "yhteiskunnan muutosten asettamiin haasteisiin" voidaan vastata. Rinne tähdentää: "Erilaiset instituutiot, järjestelmät tai instanssit eivät kuitenkaan aseta ainuttakaan vaatimusta tai tavoitetta. Niitä asettavat politiikan reaaliset päättäjät ja julkiseen keskusteluun sekä mietintötekstien laatimiseen osallistuvat henkilöt sekä heidän taustaryhmänsä. Koko tavoiteretoriikka ja myös siitä mahdollisesti seuraavat koulutuspolitiikan teot määritellään tietenkin niiden ehdoilla, jotka ovat siinä asemassa, että voivat ja haluavat saada äänensä kuuluviin."

Ari Antikaisen ja Katja Komosen osuus on suomennettu mukaelma viime vuonna International Handbook on the Sociology of Education -kirjassa ilmestyneestä artikkelista. (Handbookin toimitti Antikainen yhdessä maailmalla laajalti tunnetun koulutussosiologi Carlos A. Torresin kanssa.) Kirjoittajat esittelevät jälleen aika pe- rinpohjaisesti elämäkerta- ja elämänkulkunäkökulman perinnettä ja nykyisyyttä koulutussosiologisessa tutkimuksessa (vuoden 1996 vuosikirjahan oli kokonaan omistettu Antikaisen tutkimusryhmän oppiminen ja elämänhistoria-teemalle).

\section{KOKO ELÄMÄÄ EI PIDÄ OPINNOLLISTAA}

Oppimista kaikessa monimuotoisuudessaan on hyvin vaikeaa erottaa ihmisen muusta toiminnasta, mistä tosiasiasta kirjoittajat vetävätkin johtopäätöksiä niin tutkimuksen kuin harjoitettavan politiikan kannalta. Kasvatuksen ja koulutuksen tutkimuksessa on toki aiheellista nähdä oppiminen laajemmin, kuin perinteisesti on tehty. Ihminen oppi kokemuksen kautta kaikessa toiminnassaan kaiken aikaa. Mutta yhteiskuntapolitiikassa tulisi myös pyrkiä oppimista edistävän ja tukevan kulttuurin tukemiseen niin, että samanaikaisesti osattaisiin varoa pedagogisoimasta tai opinnollistamasta liiaksi koko yhteiskuntaa. Elämässä on muitakin tärkeitä tavoitteita kuin oppiminen ja sosiaalisilla instituutioilla on muitakin tehtäviä kuin oppiminen, Antikainen ja Komonen muistuttavat.
Ei ole myöskään viisasta ajatella, että oikeassa oppimisyhteiskunnassa kaikki olisivat oppineet tavoiterationaalisesti reflektoimaan koko ajan kaikkea tekemäänsä. Kuuliainen itsensä tarkkailu vie mielekkyyden itse toiminnasta. Yhtä kaikki tuon tuosta kuulee sanottavan, kuinka kansainvälisen kilpailukyvyn lisääminen suorastaan pakottaa meidät käyttämään kaikki tilaisuudet oppimiseen.

\section{ITSENSÄ KEHITTÄMISEN MERKITYS UNOHTUNUT}

Kaikesta ongelma- ja opiskelijakeskeisyydestä huolimatta talouden toimintaan perustuvia pakkoja korostava "elinikäisen oppimisen toinen sukupolvi" on unohtanut lähes kokonaan itsensä kehittämisen ja toteuttamisen merkityksen yksilölle itselleen ja lähiyhteisöille - miksei koko ihmiskunnalle.

Kirjan toimittaja Pekka Sallila on koonnut alkuun muutaman sivun tiivistelmän kirjan luvuista, mutta artikkeleissa esitetyn yläpuolelle kohoava nostatus kirjan lopusta puuttuu. Toisaalta nyt viimeisenä oleva Risto Rinteen artikkeli on aika lennokas päätös sekin.

Heikki Silvennoinen 